\title{
Trade-offs between foraging efficiency and pup feeding rate of lactating northern fur seals in a declining population
}

\author{
Tiphaine Jeanniard du Dot ${ }^{1,2,5, *}$, Andrew W. Trites ${ }^{1}$, John P. Y. Arnould ${ }^{3}$, \\ John R. Speakman ${ }^{4}$, Christophe Guinet ${ }^{2}$
}

\footnotetext{
${ }^{1}$ Marine Mammal Research Unit, Institute for the Oceans and Fisheries, University of British Columbia, 2202 Main Mall, AERL, Vancouver, BC, V6T1Z4, Canada

${ }^{2}$ Centre d'Etudes Biologiques de Chizé, CNRS-UMR 7372, 405 Route de Prissé la Charrière, 79360 Villiers en Bois, France

${ }^{3}$ School of Life and Environmental Sciences, Deakin University, 221 Burwood Highway, Burwood, VIC 3125, Australia

${ }^{4}$ The Institute of Biological and Environmental Sciences, Zoology Building, Tillydrone Avenue, Aberdeen AB24 2TZ, UK

${ }^{5}$ Present address: Institut Maurice-Lamontagne, Fisheries and Oceans Canada, 850 Route de la Mer, PO Box 1000, Mont-Joli, QC, G5H 3Z4, Canada
}

\begin{abstract}
Foraging strategies and their resulting efficiency (energy gain to cost ratio) affect animals' survival and reproductive success and can be linked to population dynamics. However, they have rarely been studied quantitatively in free-ranging animals. We investigated foraging strategies and efficiencies of wild northern fur seals Callorhinus ursinus during their breeding season to understand potential links to the observed population decline in the Bering Sea. We equipped 20 lactating females with biologgers to determine at-sea foraging behaviours. We measured energy expenditure while foraging using the doubly-labelled water method, and energy gained using (1) the types and energy densities of prey consumed, and (2) the number of prey capture attempts (from acceleration data). Our results show that seals employed 2 foraging strategies: one group $(40 \%)$ fed mostly in oceanic waters on small, high energy-density prey, while the other $(60 \%)$ stayed over the shallow continental shelf feeding mostly on larger, lower quality fish. Females foraging in oceanic waters captured 3 times more prey, and had double the foraging efficiencies of females that foraged on-shelf in neritic waters. However, neritic seals made comparatively shorter trips, and likely fed their pups $\sim 20$ to $25 \%$ more frequently. The presence of these strategies which either favor foraging efficiency (energy) or frequency of nursing (time) might be maintained in the population because they have similar net fitness outcomes. However, neither strategy appears to simultaneously maximize time and energy allocated to nursing, with potential impacts on the survival of pups during their first year at sea.
\end{abstract}

KEY WORDS: Foraging efficiency $\cdot$ Reproduction success $\cdot$ Northern fur seal $\cdot$ Pup growth $\cdot$ Diet

\section{INTRODUCTION}

A central concept in life-history theory is that organisms must optimally allocate resources between the competing demands of reproduction, body maintenance, and growth in order to maximize survival

${ }^{*}$ Corresponding author: tiphainejdd@gmail.com and reproductive success. Changes in environmental conditions that result in sub-optimal energy intake will likely result in animals modifying how they allocate energy. In long-lived animals, self-maintenance has priority over reproduction because fitness, and lifetime reproductive success depend on longevity

() The authors 2018. Open Access under Creative Commons by Attribution Licence. Use, distribution and reproduction are unrestricted. Authors and original publication must be credited. 
(Bouten et al. 1994). Hence, reductions in energy intake or foraging efficiency are expected to affect breeding performances before they affect adult survival. However, the extent to which reproduction is impaired by food availability depends in part on the flexibility and capacity of animals to acquire energy (foraging efficiency) and allocate it (physiological plasticity). Therefore, the extent to which an animal can adjust to localized environmental changes and the availability and distribution of prey will determine its body condition, fitness and capacity to survive and successfully reproduce.

Numbers of northern fur seals Callorhinus ursinus breeding in the central Bering Sea (St. Paul and St. George Islands) have declined by $3.5 \% \mathrm{yr}^{-1}$ for the last $20 \mathrm{yr}$ (Muto et al. 2016), as have populations of other top predators in this area (Wanless et al. 2005). Female fur seals sustain high energy output while nursing their pups for 4 mo by making frequent foraging trips at sea. The breeding season is a crucial period in the life history of otariids, when foraging success of mothers determines the quantity of energy available to transfer to their pups and ensure their post-weaning survival (Reid \& Forcada 2005). These marine predators use areas of high productivity that are linked to higher and more predictable prey concentrations (Costa 1993).

In the Bering Sea, major environmental changes starting in the mid-1970s altered the distribution and relative abundances of different species of fish (Conners et al. 2002, Grebmeier et al. 2006). The main prey available to top marine predators in the Bering Sea switched from high to low energy density prey (Trites et al. 2007, Sinclair et al. 2008). Free-ranging predators usually buffer changes in the availability of prey by changing their foraging areas. However, during the breeding season, mothers leave their pups on shore while they forage at sea, and the limited fasting abilities of a small, growing pup puts a cap on the upper end of how long the mother can spend at sea. The fasting constraints of pups and their need to grow rapidly strongly constrain the foraging range of lactating northern fur seals (central place foragers). Consequently, localised oceanographic variations within the foraging range of northern fur seals during the breeding season likely affect foraging success of fur seals and the rearing of their pups.

When faced with environmental changes, animals have to employ strategies that balance the energetic costs and time spent foraging, against the potential energy gained from prey. Foraging efficiency is the difference between the energy gained through prey intake and the energy spent to extract the prey from the environment. A decline in foraging efficiency of lactating fur seals could explain reduced reproductive success, and thus overall fitness, of the breeding females in the central Bering Sea compared to pre1970s - and consequently the declining population trend of northern fur seals. There is therefore a need to determine, at the finest scale possible, the foraging and feeding behaviours of individual fur seals to determine links between specific environmental parameters, fitness, and demographic parameters.

Estimating foraging efficiency requires measuring foraging costs and energy gain at the same time. Traditionally, foraging efficiency has not been measured, but merely inferred by comparing the change in mass before and after a foraging trip (Gentry \& Kooyman 1986, Lea et al. 2006, Luque et al. 2007), which lacks fine-scale precision (Insley et al. 2008). It is rare that both sides of the 'efficiency equation' have been studied on the same individuals (Costa 1993). The doubly-labelled water (DLW) method has been used and validated to estimate the field metabolic rate (FMR) of pinnipeds (Speakman 1997, Butler et al. 2004, Sparling et al. 2008), but has been seldom used on northern fur seals since the 1980s (Costa \& Gentry 1986, Costa 1987).

Feeding success, or the energy gained while foraging, is more difficult to measure than energy expenditure. Proxies for feeding success such as changes in mass and body composition, changes in buoyancy during drift dives, transit rate, dive shape and bout structures have all been tried and validated to some extent on marine predators under certain conditions (Hindell et al. 2010), but none of these techniques provide a quantitative measure of energy gain itself. Changes in stomach temperatures have been used in seals and birds to detect feeding events (Grémillet \& Plös 1994, Kuhn \& Costa 2006), but have been less successful in wild otariids that tend to regurgitate the devices before going to sea. However, the development of high sampling rate sensors such as tri-axial accelerometers can provide indices of prey capture attempts in marine mammals. The use of these indices, when paired with an estimate of diet composition, allows calculation of quantitative estimates of energy gained during a feeding trip. Together with measures of foraging effort, foraging efficiency of individuals can then be calculated.

Comparing foraging efficiencies relative to foraging strategies can further shed light on the trade-offs animals make between the 2 main currencies in animal bioenergetics: time and energy. It is these tradeoffs that likely impact the energy reserves that mothers have to feed their pups, which in turn influence 
the chances of pups surviving their first year at sea (Doidge \& Croxall 1989, Baker \& Fowler 1992, Boltnev et al. 1998, McMahon et al. 2000, Hall et al. 2001, Beauplet et al. 2005). In this context, the objectives of our study were (1) to determine the foraging strategies of lactating northern fur seals, including locations, diving patterns and targeted prey, (2) to measure foraging efficiency (foraging gain/cost ratio) and determine how it relates to foraging strategy, and (3) to assess how different foraging strategies and efficiencies might be related to reproductive success and the declining trend of the fur seal population breeding in the central Bering Sea.

\section{MATERIALS AND METHODS}

\section{Data collection}

Data were collected from 20 lactating northern fur seals at Reef Rookery on St. Paul Island (Bering Sea, $57^{\circ} 6^{\prime} \mathrm{N}$ to $170^{\circ} 17^{\prime} \mathrm{W}$ ) during the breeding season (Aug-Sep 2011) under US National Marine Fisheries Service (NMFS) permit \#14329-01 and University of British Columbia (UBC) animal care permit \#A100364. Data collection procedures were similar to those reported in Jeanniard du Dot et al. (2017b). In short, females were captured using a hoop net, anesthetized (gas anesthesia with isoflurane), measured and weighed, and equipped with biologgers. They were also injected with DLW, and had blood samples drawn to measure metabolic rates (see details below). Animals were released upon full recovery from anesthesia, and recaptured after a single foraging trip at sea using the same methods.

\section{Energy expenditure, foraging behaviours and prey capture attempts}

Based on GPS tracks and on stable isotope $\delta^{13} \mathrm{C}$ and $\delta^{15} \mathrm{~N}$ values (which indicate foraging habitat and trophic level, respectively) measured from these same animals for another study (Jeanniard du Dot et al. 2017a), 8 of the 20 tagged females went to the oceanic waters to forage in the deep basin of the Bering Sea (up to $3000 \mathrm{~m}$ deep), hereafter called 'oceanic' females, and the remaining 12 stayed over the shallow Bering Sea shelf (0 to $200 \mathrm{~m}$ deep), hereafter called 'neritic' females (Fig. 1). Analyses and calculations of the energy expenditure, foraging behaviours and prey capture attempts are detailed in Jeanniard du Dot et al. (2017c) and Jeanniard du Dot et al. (2017b). In brief, measurements of daily energy expenditure (DEE, $\mathrm{kJ} \mathrm{d}^{-1}$ ) were performed using the DLW method, where a weighed dose of DLW (0.3 to $0.6 \mathrm{~g} \mathrm{~kg}^{-1}$ body mass) was intravenously injected via catheter into the hind-flipper before a second blood sample was taken following a 2 -h period of equilibration. A final blood sample was drawn to determine isotope levels of ${ }^{2} \mathrm{H}$ and ${ }^{18} \mathrm{O}$ at the end of the foraging trip upon recapture. We used a 2-pool model and a plateau method to calculate initial dilution spaces, and the equation from Speakman et al. (1993) to account for evaporative water loss when calculating metabolic, as well as a respiratory quotient of 0.80 to convert $\mathrm{CO}_{2}$ production rates into DEE (Sparling et al. 2008, Dalton et al. 2014). Energy spent during the 'non-foraging' time was corrected by subtracting onland energy expenditure from the total estimate using previously determined values specifically for lactating northern fur seals $\left(4.67 \mathrm{~W} \mathrm{~kg}^{-1}\right.$, in Gentry \& Kooyman 1986). Error in individual DEE for each seal was calculated by generating 1000 values following a normal distribution of $1.8 \pm 7.2 \%$ of the measured values of DLW, based on the error estimated by Dalton et al. (2014) when DLW was compared to respirometry on northern fur seals.

The fur seals were also equipped with Daily Diary tags (DDT, Wildlife Computers) recording tri-axial acceleration and tri-axial magnetic field at $16 \mathrm{~Hz}$ and depth, light level, and water temperature at $1 \mathrm{~Hz}$. This tag was positioned as close as possible to the center of mass of the animal to optimize measurements of the overall dynamic body acceleration (Halsey et al. 2009), which has been calculated for these animals in another study. We used depth data to determine diving behaviours using a custom-made R programme previously developed for Antarctic fur seals. Dives were defined as periods of time that animals spent under water below a minimum depth of $3 \mathrm{~m}$ and for a minimum of $4 \mathrm{~s}$ until they returned to the surface. Dives were classified as 'benthic' when animals dove to $95 \%$ of the bathymetric depth. Fastloc GPS MK10 loggers (Wildlife Computers) were glued slightly below the DDT along the spine and recorded GPS coordinates along the track of the animal at sea, as well as depth and water temperature at $1 \mathrm{~Hz}$. Finally, GCDC X6 or X8 accelerometers glued to the fur on the head of the animals recorded triaxial acceleration at 16 or $20 \mathrm{~Hz}$ to measure prey capture attempts (PrCA). PrCA have been traditionally measured using head accelerometers (Viviant et al. 2010, Gallon et al. 2013); however, we found that back acceleration can provide an accurate estimate of PrCA providing a correction factor is used (Jean- 

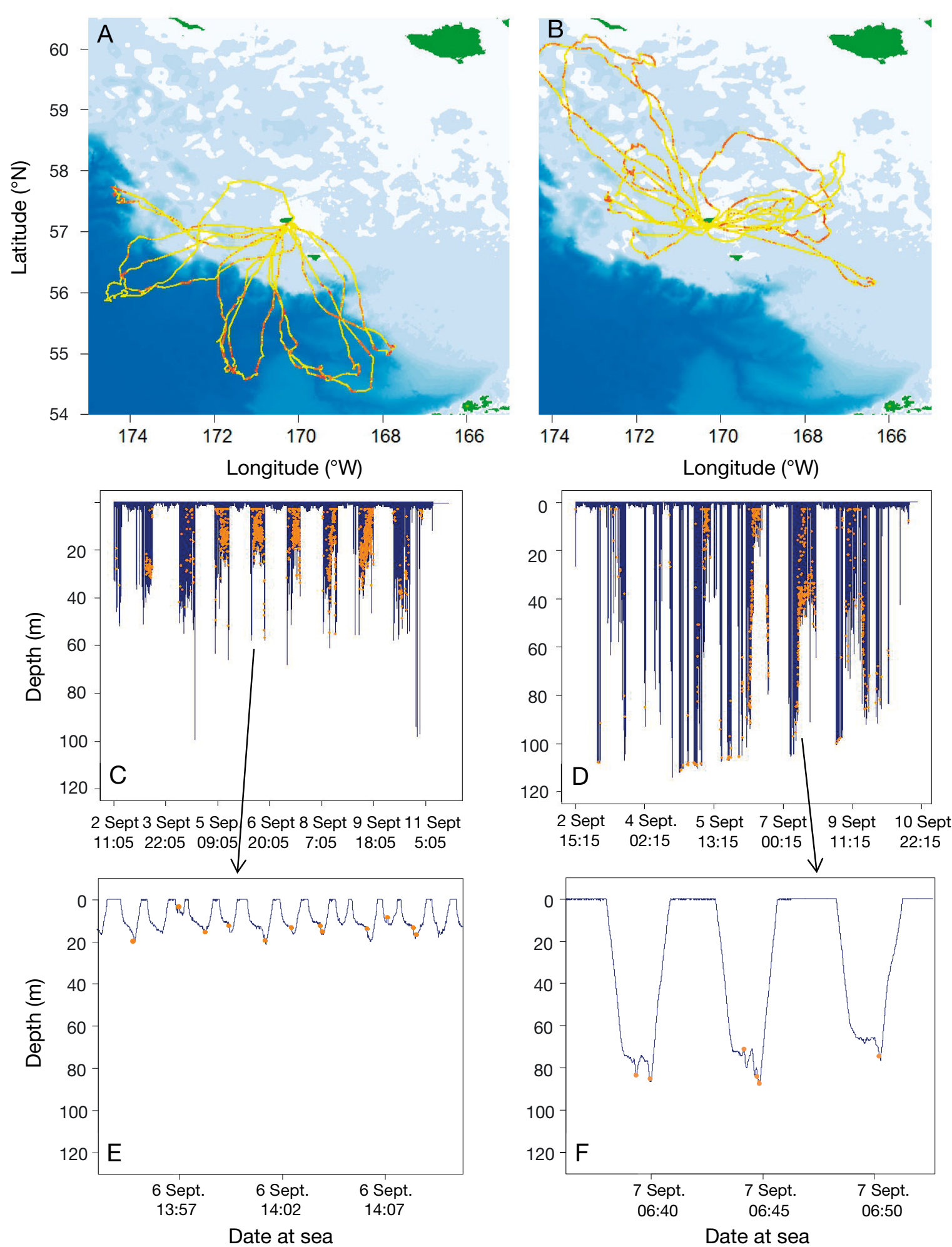

Fig. 1. $(A, B)$ Foraging tracks and dive profiles over a $(C, D)$ full foraging trip, and $(E, F)$ a 5 -min period of diving for lactating northern fur seals from Reef Rookery on St. Paul Island in the Bering Sea. Fur seals foraged either off the shelf in oceanic waters (left panels, $\mathrm{n}=8$ ) or on the shelf in neritic waters (right panels, $\mathrm{n}=12$ ). Orange dots show spatial distribution of prey capture attempts in Panels A and B (with yellow representing no prey capture attempt) and distribution of prey capture attempts over time and depth profiles in Panels C-F 
niard du Dot et al. 2017b), as has also been found to be the case for elephant seals (C. Guinet pers. obs.). PrCA were measured while animals were diving below $3 \mathrm{~m}$ depth using acceleration data recorded on the head or back of animals using the same method as described in Jeanniard du Dot et al. (2017b). In brief, the heave $(\mathrm{z})$ and surge $(\mathrm{x})$ raw acceleration channels were filtered using a 3rd order high-pass filter at $3 \mathrm{~Hz}$. The resulting dynamic acceleration signals were then summed and a running variance was applied over a 2-s window on which a cluster analysis was applied (k-mean function in R, 2 clusters), which provided each animal with an individual threshold, above which the signal corresponded to a PrCA. PrCA represents all attempts at capturing prey, i.e. success could not be verified. We nevertheless used PrCA as a proxy for feeding rate (Volpov et al. 2015) while accounting for error (under- or overestimation of effective prey captures) in individual PrCA for each seal. The detection rate (true positive rate) of PrCA is known to range from 68 to $97 \%$ (i.e. differnce from $100 \%$ representing the degree of underestimation of true $\operatorname{PrCA}$ ), while the false positive rate ranges from 6 to $48 \%$ (representing the degree of overestimation of true PrCA) in Steller sea lions and Australian fur seals (Viviant et al. 2010, Volpov et al. 2015). We thus modeled uncertainties around the measured individual PrCA value using these true positive and false positive errors between the ranges mentioned above generated by a uniform distribution using a Monte Carlo approach (1000 values generated).

Each seal performed a different number of dives per trip. The dive depth and dive duration for each individual was calculated as an average over their foraging trip (dives are nested within individuals). To account for the multiple measures within an individual over the trip and obtain means for the group weighted by number of dives that each individual performed, the statistical difference between groups (oceanic versus neritic) for dive depth and dive duration were calculated using linear mixed effect models. We used group as a fixed effect and individual as a random effect. Model assumptions were verified and any autocorrelation or heterogeneity of variances of within-group residuals were corrected as outlined in Pinheiro \& Bates (2000). Statistical differences between groups in other parameters (that were single measures or counts over the foraging trips, or measures normalized by a time period) from Table 1 were tested with 2 -sample $t$-tests $(\alpha=0.05)$ or Mann-Whitney tests depending on normality.

\section{Diet estimates}

Based on analyses of scats, of $\delta^{13} \mathrm{C}$ and $\delta^{15} \mathrm{~N}$ values in blood and of GPS locations of the females we tracked (detailed in Jeanniard du Dot et al. 2017a), northern fur seals were found to have 2 different diets depending on their foraging strategy, i.e. whether they fed on-shelf in neritic waters or off-shelf in oceanic waters. We thus assigned one or the other of these 2 diet compositions to individual females based on their respective foraging strategies. Stable isotope $\delta^{13} \mathrm{C}$ and $\delta^{15} \mathrm{~N}$ values of the oceanic females of this study are not significantly different from the values found for females breeding on Bogoslof Island in the southern Bering Sea (see Fig. 3 in Zeppelin \& Orr 2010 and Fig. 2 in Jeanniard du Dot et al. 2017a), which indicate similar foraging habitat and diet. We thus assumed that oceanic females fed on a diet similar to the one estimated on Bogoslof Island in 2009 (Trites et al. 2015), as thoroughly discussed in Jeanniard du Dot et al. (2017a). We assigned the diet composition determined by scats collected on reef rookery in 2011 to neritic females as scats represent prey consumed within the previous 24 to $48 \mathrm{~h}$, i.e. on the shelf. To determine the size of prey consumed, we used scat hard-part remains collected on Reef Rookery in the 2011 group (representative of prey sizes that particular year) and hard parts recovered from scats collected at Bogoslof Island in 2009 whenever fish specific to the oceanic diet were not recovered in the collected scats on Reef Rookery in 2011 (Trites et al. 2015, Jeanniard du Dot et al. 2017a).

For each prey species found in the 2 diets (i), the energy density $\left(E D_{i}\right)$ expressed in wet mass was estimated from published values (Perez 1994, Van Pelt et al. 1997, Paul \& Paul 1999, Logerwell \& Christiansen 2000, Iverson et al. 2002, Gende et al. 2004, Andrews et al. 2009, Whitman 2010, Vollenweider et al. 2011). Energy density of walleye pollock differs by age class (Paul \& Paul 1999), so we obtained the overall energy density of pollock by accounting for the proportion of each age class (determined from their size) in the diet, i.e. $85 \%$ of age- 0 at $4.00 \mathrm{~kJ} \mathrm{~g}^{-1}$ and $15 \%$ of age-1+ at $4.73 \mathrm{~kJ} \mathrm{~g}^{-1}$ (Whitman 2010, Heintz et al. 2013). Salmonids were identified at the species level from the DNA meta-barcoding method that provides diet information at a finer taxonomic level than the hard part method. We thus calculated the proportion of each salmon species in the overall diet of fur seals. Then, the energy density of salmon species found in Alaskan waters (Hendry \& Berg 1999, Anthony et al. 2000, Rosen \& Trites 2000, Gende et al. 2004) was averaged and weighted by the proportion of different 
Table 1. Mean foraging and metabolic parameters of female northern fur seals (NFS) foraging in neritic waters on the Bering Sea shelf $(n=12)$ or in oceanic waters in the Bering Sea basin $(n=8)$ for 1 trip at sea. Values are mean $\pm S E$, and letters in superscript indicate significant differences between the groups $(\mathrm{p}<0.05)$. Values of similar parameters for female Antarctic fur seals (AFS) are added for comparison (from Jeanniard du Dot et al. 2017b). EE: energy expenditure; PrCA: prey capture attempts; ED: energy density; $E C_{p}$ : energy content prey; EGain: energy gain

\begin{tabular}{|c|c|c|c|}
\hline Parameter & Neritic NFS & Oceanic NFS & AFS \\
\hline Mass pre-departure (kg) & $39.4 \pm 2.0^{\mathrm{a}}$ & $35.7 \pm 1.2^{\mathrm{a}}$ & $31.1 \pm 0.9^{b}$ \\
\hline Trip duration $(\mathrm{d})$ & $7.1 \pm 2.4^{\mathrm{a}}$ & $9.7 \pm 1.8^{\mathrm{b}}$ & $7.6 \pm 3.8^{\mathrm{a}}$ \\
\hline Distance travelled $(\mathrm{km})$ & $655 \pm 63^{a}$ & $892 \pm 51^{b}$ & $635 \pm 77^{a}$ \\
\hline Number of dives & $1831 \pm 374^{\mathrm{a}}$ & $3631 \pm 313^{b}$ & $3949 \pm 597^{b}$ \\
\hline Dive depth (m) & $26.8 \pm 3.3^{\mathrm{a}}$ & $16.9 \pm 2.0^{\mathrm{b}}$ & $19.9 \pm 2.7^{b}$ \\
\hline Dive duration (s) & $79.8 \pm 8.5^{\mathrm{b}}$ & $37.3 \pm 6.4^{\mathrm{a}}$ & $42.6 \pm 4.5^{\mathrm{a}}$ \\
\hline Benthic dives (\%) & $15.2 \pm 2.6^{\mathrm{a}}$ & $2.2 \pm 0.4^{\mathrm{b}}$ & $0 \pm 0^{\mathrm{b}}$ \\
\hline Time diving $(\%)$ & $33.1 \pm 3.1^{\mathrm{a}}$ & $24.7 \pm 0.8^{\mathrm{b}}$ & $29.0 \pm 0.7^{\mathrm{a}}$ \\
\hline Time transiting $(\%)$ & $28.3 \pm 2.3$ & $32.0 \pm 2.2$ & $26.4 \pm 1.6$ \\
\hline Time diving $(\mathrm{h})$ & $55.8 \pm 7.9$ & $55.1 \pm 3.5$ & $51.3 \pm 5.9$ \\
\hline Time transiting $(\mathrm{h})$ & $49.0 \pm 7.2^{\mathrm{a}}$ & $72.2 \pm 7.8^{\mathrm{b}}$ & $49.8 \pm 7.9^{\mathrm{a}}$ \\
\hline At-sea metabolic rate $\left(\mathrm{MJ} \mathrm{d}^{-1} \mathrm{~kg}^{-1}\right)$ & $0.56 \pm 0.05$ & $0.54 \pm 0.07$ & $0.59 \pm 0.04$ \\
\hline Total EE $\left(\mathrm{MJ} \mathrm{kg}^{-1}\right)$ & $3.7 \pm 0.4$ & $4.9 \pm 0.8$ & $4.1 \pm 0.6$ \\
\hline EE diving (MJ kg $\left.{ }^{-1}\right)$ & $2.0 \pm 0.3$ & $2.0 \pm 0.2$ & $2.2 \pm 0.3$ \\
\hline EE transiting $\left(\mathrm{MJ} \mathrm{kg}^{-1}\right)$ & $1.0 \pm 0.2^{\mathrm{a}}$ & $1.6 \pm 0.2^{\mathrm{b}}$ & $1.3 \pm 0.2^{\mathrm{ab}}$ \\
\hline PrCA per minute of diving & $0.43 \pm 0.37^{\mathrm{a}}$ & $1.87 \pm 38^{\mathrm{b}}$ & $1.37 \pm 0.22^{\mathrm{b}}$ \\
\hline PrCA per capturing dive & $1.77 \pm 0.23$ & $1.75 \pm 0.17$ & $2.04 \pm 0.11$ \\
\hline $\mathrm{PrCA} \mathrm{d}^{-1}$ & $100 \pm 26^{\mathrm{a}}$ & $275 \pm 39^{b}$ & $336 \pm 38^{\mathrm{b}}$ \\
\hline PrCA per trip & $789 \pm 163^{\mathrm{a}}$ & $2404 \pm 338^{\mathrm{b}}$ & $2328 \pm 387^{b}$ \\
\hline $\mathrm{ED}_{\text {Diet }}\left(\mathrm{kJ} \mathrm{g}^{-1}\right)$ & $4.28 \pm 0.72$ & $5.75 \pm 1.44$ & $7.75 \pm 2.47$ \\
\hline$E C_{p}(\mathrm{~kJ})$ & $330.60 \pm 11.20$ & $194.94 \pm 8.13$ & $152.46 \pm 1.08$ \\
\hline EGain per dive $(\mathrm{kJ})$ & $179.6 \pm 49.8$ & $188.5 \pm 34.4$ & $177.7 \pm 21.4$ \\
\hline EGain per time diving $\left(\mathrm{kJ} \min ^{-1}\right)$ & $84.2 \pm 16.5^{\mathrm{a}}$ & $145.9 \pm 24.4^{b}$ & $130.6 \pm 16.3^{b}$ \\
\hline EGain per time at sea $\left(\mathrm{kJ} \mathrm{min}^{-1}\right)$ & $26.2 \pm 6.2^{\mathrm{a}}$ & $35.21 \pm 5.4^{\mathrm{b}}$ & $37.6 \pm 4.6^{\mathrm{b}}$ \\
\hline Foraging efficiency & $1.51 \pm 0.69^{\mathrm{a}}$ & $3.03 \pm 0.60^{b}$ & $3.44 \pm 0.45^{\mathrm{b}}$ \\
\hline
\end{tabular}

species identified in the same scats with the DNA meta-barcoding method (Jeanniard du Dot et al. 2017a) to obtain an overall salmonid energy density representative of the fur seal diet. The variations in prey body mass and energy density values were estimated from their reported ranges converted as mean \pm SD. Whenever information was missing for prey with low frequencies of occurrence in the diet, we replaced it with the energy density of the closest related prey item or with the average of the energy content for the specific prey group.

We calculated energy density in diet $\left(E D_{\text {Diet }}\right)$ by averaging $E D_{i}$ values, weighted by their proportion of the corresponding prey item within the diet $\left(P_{i}\right)$, over the number of prey in the $\operatorname{diet}(N)$ :

$$
E D_{\text {Diet }}=\frac{\sum\left(E D_{i} \times P_{i}\right)}{N}
$$

We then estimated the gross energy intake $(\mathrm{kJ})$ for each prey ingested by deriving the size of prey ingested from hard-part remains in the collected scats. We relied on all identifiable bones to estimate number of prey items in each scat, but only used unbroken otoliths in good or fair condition to estimate fish length (Tollit et al. 2004). Lengths of otoliths were measured using the method described in Harvey et al. (2000), and correction factors were applied to these measured lengths to account for digestion whenever a speciesspecific correction factor was available (i.e. 1.1691 for Atka mackerel and 1.1593 for walleye pollock; Tollit et al. 2004). Measured otoliths of the same size $( \pm 0.1 \mathrm{~mm})$ were paired and assumed to come from the same fish (Hunt et al. 1980, Dragoo 1991).

Squid beaks were measured using guidelines from Wolff (1984) but we were not able to identify them to the species level (including using the DNA meta-barcoding method; see Jeanniard du Dot et al. 2017a). As northern fur seals are known to mostly consume squids from the gonatid family in the Bering Sea (Gonatopsis borealis and Berryteuthis magister; Gudmundson et al. 2006) we used the general size equation available for this family (Clarke 1962, 1986) with no correction factor (Tollit et al. 1997).

Fish otolith lengths (OL) or squid lower beak rostrum lengths (LRL, $\mathrm{mm}$ ) were converted to fish/squid length ( $\mathrm{FL}, \mathrm{cm})$, and then body mass (BM, g) using the species-specific allometric equations listed in the 
section 'Equations to estimate body length and mass of fish and squid' in the Supplement at www.int-res. com/articles/suppl/m600p207_supp.pdf. For species of fish found in the scats that were identified by other hard parts than otoliths (vertebrae, gill rakers, etc.), the size of hard parts was compared with those of reference skeleton from Pacific ID Inc. and allocated to a range of sizes summarized in both Table 1 and Fig. 6 of Trites \& Calkins (2008). We estimated average size \pm SE of these fish species by simulating random selection of fish sizes from the range of sizes in each category using a uniform distribution (1000 simulations).

Once the mass $\left(B M_{i}, g\right)$ and energy density $\left(E D_{i}\right.$, $\mathrm{kJ} \mathrm{g}^{-1}$ ) of each prey item were estimated, the average energy content of a prey from a specific species $\left(E C_{i r}\right.$ $\mathrm{kJ}$ ) was calculated as:

$$
E C_{i}=B M_{i} \times E D_{i}
$$

and the average energy content of a non-specific 'average' prey $\left(E C_{p}, \mathrm{~kJ}\right)$ in the diets of neritic and oceanic fur seals was calculated by weighting the energy content of a specific prey item by its relative proportion in the diet $\left(P_{i}\right)$ :

$$
E C_{p}=\Sigma\left(E C_{i} \times P_{i}\right)
$$

We calculated mean $\pm \mathrm{SD}$ of $E C_{i}$ by generating 1000 values of mass and 1000 values of $E D_{i}$ using normal distributions of their respective means $\pm \mathrm{SD}$. Means $\pm \mathrm{SD}$ of $E D_{\text {Diet, }}$ and $E C_{p}$ in the 2 diets were calculated by generating values of $E C_{i}$ and $E D_{i}$ for each prey type in proportion to their respective importance in the diet (i.e. $P_{i}$ ) out of 1000 values from normal distributions using their respective mean $\pm \mathrm{SD}$. Prey species with no $E D_{i}$ or $E C_{i}$ values were substituted by the average $E D$ or $E C$ from their respective prey group (e.g. gadid, cephalopod, etc.) weighted by their own proportion within the diet. As the prey group 'other' did not have values for mass or energy density, we used an average of the rest of the diet weighted by its relative importance in the diet for prey species in this group.

\section{Foraging efficiency}

For each seal $(s)$, the foraging efficiency $\left(F E_{s}\right)$ was calculated using the method detailed in (Jeanniard du Dot et al. 2017b). In brief, $F E_{s}$ is the ratio between the daily energy expenditure at sea for each animal $\left(D E E_{s}\right)$ obtained from the DLW measures and energy gained while foraging at sea. For each seal, we estimated energy gained as the energy content of an 'average' prey in the diet (i.e. $E C_{p}$ ) multiplied by the number of times the seal attempted to capture a prey $\left(\operatorname{PrCA} A_{s}\right)$

$$
F E_{s}=\frac{E C_{p} \times \operatorname{PrCA} A_{s}}{D E E_{s}}
$$

There are a number of potential biases that could affect our analyses. These include the potential for DLW to either over- or under-estimate metabolic rate at the individual level, and for there to be errors in estimated diet composition, fish size and energy density from scat hard parts due to differential digestion and retention rates. Similarly, $\operatorname{PrCA} A_{s}$ values reflect capture attempts and not actual captures. As a result of such potential errors, we applied correction factors when available, and included uncertainties in the final calculations. Uncertainty around $F E_{s}$ was calculated using 1000 Monte Carlo simulations that reflected errors in the 3 equation parameters, i.e. the error in individual $D E E_{s}, E C_{p}$ and $\operatorname{PrCA}_{s}$ for each seal, as mentioned in the respective sections above and described in detail in Jeanniard du Dot et al. (2017b). Mean \pm SD of $F E_{s}$ for each seal was calculated over the 1000 generated $\operatorname{PrCA}_{s}, D E E_{s}$ and $E C_{p}$ values using Eq. (4). We calculated uncertainty over the average $F E$ using the bootstrap method over 1000 simulations, where the random sampling with replacement was drawn from the 1000 values of $F E_{i}$ generated per animal in the study.

A sensitivity analysis was performed to estimate the contribution of each of the input variables uncertainty to the overall variance in the resulting foraging efficiency. This was done by computing the standardized regression coefficients (SRC), bias and $95 \%$ confidence intervals for each of the input variables using the src function in R (sensitivity library, R3.0.3) over 1000 simulated values.

\section{RESULTS}

\section{Foraging behaviours}

The foraging tracks of the 8 oceanic females and 12 neritic females are shown on Fig. 1. Overall, females weighed $( \pm \mathrm{SE}) 37.9 \pm 1.34 \mathrm{~kg}$ prior to departure (range $30.8-55.6 \mathrm{~kg}, \mathrm{n}=20$ ). Twelve females gained mass ( $0.7-5.2 \mathrm{~kg}$ gained), and 8 lost mass during their foraging trip $(0.2-4.2 \mathrm{~kg}$ lost). This corresponds to an overall gain of $3.5 \pm 1.8 \%$ of initial body mass for the 20 females (range from 9.9\% lost to $16.1 \%$ gained, and an average net gain of $3.2 \pm 2.5 \%$ for neritic females and $3.9 \pm 2.7 \%$ for oceanic fe- 
males). Foraging trips lasted $7.96 \pm 2.17 \mathrm{~d}$ (range 4.26-12.03 d) and average horizontal (surface) distance travelled was $\sim 750 \pm 50 \mathrm{~km}$ (range 391$1200 \mathrm{~km}$ ). Oceanic females spent on average $2.5 \mathrm{~d}$ more at sea during their foraging and travelled $200 \mathrm{~km}$ more than neritic females (both $\mathrm{p}<0.009$; Fig. 1, Table 1).

Neritic females regularly performed benthic dives $(15.2 \pm 2.6 \%$ of all dives) and occasionally foraged during the day, while oceanic females rarely did so $(2.2 \pm 0.4 \%$ of all dives and $0 \%$ when off the shelf) and were nocturnal divers (Table 1, Fig. 1C,D). Neritic females also performed significantly fewer foraging dives than the oceanic ones $(p<0.001)$, but their dives were almost twice as deep and lasted twice as long $(\mathrm{p}<0.05$; see details in Table 1$)$. In addition, $\sim 73 \%$ of oceanic female dives and $~ 55 \%$ of neritic female dives were shallower than $15 \mathrm{~m}$. Overall, oceanic seals spent significantly less time diving and more time transiting over the full foraging trip time scale compared with neritic females (both $\mathrm{p}<0.05$; Table 1). In other words, oceanic females travelled $\sim 30 \mathrm{~h}$ more than neritic females, for the same number of hours spent diving over the - on average longer foraging trip (Fig. 1, Table 1). In addition, females that were in better body condition (mass/length) prior to starting a foraging trip made shorter foraging trips compared to females in poorer body condition (slope, $\mathrm{p}=0.006, \mathrm{R}^{2}=0.58 ;$ Fig. 2). In the model (Fig. 2), the slope was similar for both groups (i.e. same relation between body condition and subsequent time at sea) but the intercept was higher for the oceanic group $(+1.98 \mathrm{~d}, \mathrm{p}=0.015)$, which reflects the longer trip durations of females foraging off-shelf.

\section{Energetic cost of foraging}

Rates of energy expenditure per day at sea were not statistically different between foraging strategies whether mass-corrected or not $(p>0.07$; Table 1$)$. This translated into oceanic females spending slightly, but not significantly more energy per trip than neritic females overall ( $p>0.09$ ), even though they spent more energy transiting to and from feeding grounds $(\mathrm{p}=0.06$; Table 1$)$.

\section{Prey capture attempts}

Oceanic females attempted to capture prey more often per dive $(0.76 \pm 0.09$ PrCA per dive) than neritic females $(0.46 \pm 0.09$ PrCA per dive, $p=0.004)$. Since

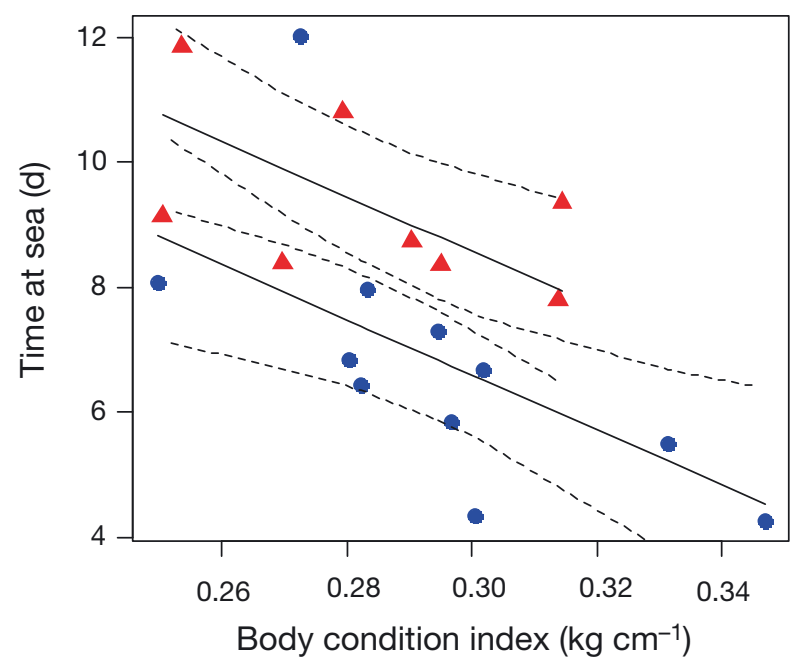

Fig. 2. Time spent at sea by female northern fur seals $(n=20)$ during a foraging trip from Reef Rookery on St. Paul Island as a function of their own body condition (mass/length) prior to leaving the rookery, for oceanic females foraging off the shelf (red triangles) and neritic females foraging on the shelf (blue circles). Solid lines show the results of the linear regression fitted between the 2 parameters (slopes not different between the group, i.e. all seals will increase their time at sea to the same extent for a given decrease in body condition no matter what foraging group [oceanic or neritic] they belong to) and the dashed lines represent the $95 \% \mathrm{CI}$ of the predicted values $\left(F=10.95, \mathrm{p}=0.001, \mathrm{R}^{2}=0.58\right)$

oceanic females dove more often at shallower depths and for shorter duration, this translated into a greater rate of capture per min spent diving for oceanic (1.87 \pm 0.38 PrCA $\mathrm{min}^{-1}$ spent diving) than neritic females $\left(0.43 \pm 0.37 \operatorname{PrCA~min}^{-1}, p=0.016\right)$. However, the number of attempts to capture prey was similar for both groups ( 1.76 PrCA per dive, $\mathrm{p}=0.73)$ when only dives in which at least one PrCA occurred were considered. Overall, neritic females attempted to capture prey nearly 3 times less often than oceanic females per day of foraging $\left(100 \pm 26\right.$ vs. $275 \pm 39 \mathrm{PrCA} \mathrm{d}^{-1}$, respectively; $\mathrm{p}=0.024)$ or per trip $(789 \pm 163$ vs. $2404 \pm$ 338 PrCA per trip, respectively; $\mathrm{p}=0.003$; Fig. 1 , Table 1). Most of the PrCA occurred during nighttime $(92.9 \pm$ $2.9 \%$ for neritic females and $99.0 \pm 0.4 \%$ for oceanic females; $p=0.05$ ). Visually, PrCA for oceanic females were localized to small and specific areas (orange dots on Fig. 1A), while neritic females had greater geographic and temporal spread in feeding areas (Fig. 1B).

\section{Diet and prey energy contents}

Diet composition of the females depended on their foraging strategy (Table 2) as shown in Jeanniard du Dot et al. (2017a). Neritic females mostly consumed 
Table 2. Proportion, calculated as split-sample frequency of occurrence (SSFO), average prey mass, prey energy density (ED) and prey energy content (EC) for different prey groups in diets of female northern fur seals (NFS) breeding on rookeries on St. Paul Island (representative of the 'neritic' group), and on Bogoslof Island (representative of the 'oceanic' group; Jeanniard du Dot et al. 2017a). Prey groups labelled 'Other' were assigned average diet values. SSFO values were obtained from morphological identification of hardpart remains in our study and from collection of samples of Bogoslof Island rookeries in 2009. Mass was calculated from the size of hard-part remains. NA: data not available

\begin{tabular}{|c|c|c|c|c|}
\hline Prey group & SSFO $(\%)$ & Mass (g) & $\mathrm{ED}\left(\mathrm{kJ} \mathrm{g}^{-1}\right)$ & $\mathrm{EC}(\mathrm{kJ})$ \\
\hline \multicolumn{5}{|l|}{ Neritic NFS } \\
\hline Gadid & 69.75 & $15.49 \pm 0.13$ & $4.09 \pm 0.35$ & $67.859 \pm 0.28$ \\
\hline Cephalopod & 12.28 & $3.74 \pm 1.16$ & $4.76 \pm 0.11$ & $17.79 \pm 0.04$ \\
\hline Salmon & 6.03 & $797.78 \pm 35.65$ & $5.53 \pm 0.30$ & $4425.00 \pm 9.80$ \\
\hline Hexagrammid & 3.64 & $18.67 \pm 2.48$ & $3.90 \pm 0.23$ & $75.19 \pm 0.31$ \\
\hline Mesopelagic & 2.42 & $3.87 \pm 0.25$ & $5.67 \pm 0.25$ & $21.91 \pm 0.05$ \\
\hline Forage & 1.53 & $10.69 \pm 0.19$ & $4.54 \pm 0.66$ & $49.61 \pm 1.34$ \\
\hline Flatfish & 0.28 & $3.78 \pm 0.01$ & $5.14 \pm 0.65$ & $19.45 \pm 0.08$ \\
\hline Other & 4.08 & NA & $4.28 \pm 0.72$ & $330.60 \pm 11.02$ \\
\hline Total diet & & & $4.28 \pm 0.72$ & $330.60 \pm 11.02$ \\
\hline \multicolumn{5}{|l|}{ Oceanic NFS } \\
\hline Gadid & 0.86 & $16.48 \pm 0.11$ & $4.12 \pm 0.33$ & $67.87 \pm 0.24$ \\
\hline Cephalopod & 42.70 & $3.74 \pm 1.16$ & $4.76 \pm 0.11$ & $17.79 \pm 0.04$ \\
\hline Salmon & 3.87 & $797.78 \pm 282.00$ & $5.53 \pm 0.30$ & $4425.00 \pm 9.80$ \\
\hline Hexagrammid & 0.60 & $18.69 \pm 2.37$ & $4.02 \pm 0.08$ & $75.19 \pm 0.29$ \\
\hline Mesopelagic & 48.97 & $3.77 \pm 0.52$ & $5.85 \pm 0.88$ & $21.68 \pm 0.01$ \\
\hline Forage & 1.55 & $16.47 \pm 0.51$ & $5.47 \pm 0.57$ & $92.28 \pm 3.14$ \\
\hline Other & 1.46 & NA & $5.75 \pm 1.44$ & $194.94 \pm 8.13$ \\
\hline Total diet & & & $5.75 \pm 1.44$ & $194.94 \pm 8.13$ \\
\hline
\end{tabular}

males at $5.75 \pm 1.44 \mathrm{~kJ} \mathrm{~g}^{-1}(\mathrm{p}<0.03)$. However, due to the overall smaller size of prey ingested, the energy content per prey ingested (i.e. $E C_{p}$ ) was only $194.94 \pm 8.13 \mathrm{~kJ}(\mathrm{p}<0.001$; Table 2).

\section{Foraging efficiency}

The calculated energy gains per dive were similar between oceanic and neritic groups ( $p=0.82$; Table 1$)$, but this translated into a lower rate of energy gain per minute of diving $(\mathrm{p}=$ 0.02 ; Table 1) for neritic females $\left(84.2 \pm 16.5 \mathrm{~kJ} \mathrm{m^{-1 }}\right)$ compared to oceanic females $\left(145.9 \pm 24.4 \mathrm{~kJ} \mathrm{~min}^{-1}\right)$. Similarly, neritic females gained less energy per minute spent at sea over the foraging trip $\left(26.2 \pm 6.2 \mathrm{~kJ} \mathrm{~min}^{-1}\right)$ than oceanic females $(35.21 \pm 5.4 \mathrm{~kJ}$ $\min ^{-1}, \mathrm{p}=0.05$ ).

Based on the foregoing, the resulting average foraging efficiency of all individuals for which simultaneous measures of energy expenditure and prey capture attempts were available (4 animals were missing DLW measgadids $(\sim 70 \%)$, cephalopods $(\sim 12 \%)$ and salmon $(\sim 6 \%)$, while diets of oceanic females consisted mostly of mesopelagic fish $(\sim 49 \%)$, cephalopods $(\sim 43 \%)$ and salmon ( 4\%) (Trites et al. 2015, Jeanniard du Dot et al. 2017a). Analyses of prey size from otoliths, beaks and other bone structures in the scats showed that adult female fur seals preyed mostly on small fish (3 to $20 \mathrm{~g}$ ). For example, the sizes of ingested pollock corresponded mostly to age-0 and age-1 fish (Fig. 3). The only exception was salmonids, which were $\sim 31 \mathrm{~cm}$ long and weighed $\sim 800 \mathrm{~g}$. Energy density of each major fish species ranged from $\sim 3.5 \mathrm{~kJ}$ $\mathrm{g}^{-1}$ for flatfish, to $\sim 9 \mathrm{~kJ} \mathrm{~g}^{-1}$ for northern lampfish (Table S1 in the Supplement). These sizes translated into energy content of prey groups ranging from 20 to $75 \mathrm{~kJ}$, except for larger salmon that reached $\sim 4500 \mathrm{~kJ}$ (Table 2). Mass, energy density and energy content of individual prey species are detailed in Table S1. The total energy density of diet (i.e. $E D_{\text {Diet }}$ ) for neritic females was $4.28 \pm 0.72 \mathrm{~kJ} \mathrm{~g}^{-1}$. Salmonids and gadids had the highest energy content per prey ingested (i.e. $\left.E C_{p}\right)$, with average values of $330.60 \pm 11.02 \mathrm{~kJ}$ per prey. The energy density of the diet (i.e. $E D_{\text {Diet }}$ ) for oceanic females was greater than that for neritic fe- urement and/or acceleration data) ranged from 0.42 to 5.40 (Table 3). Foraging efficiency was lower for neritic females $(1.51 \pm 0.69,95 \%$ CI: $0.86-2.42)$ than for oceanic females $(3.03 \pm 0.60,95 \%$ CI: $2.17-4.02$; $\mathrm{p}=0.05)$.

Sensitivity analyses showed that the largest contributor to the uncertainty around FE was related to PrCA estimates (Table S2), This was not surprising given that different validation studies have not consistently agreed on their detection rates and false positive rates (Viviant et al. 2010, Volpov et al. 2015). Errors associated with mass of the prey affected FE more than energy density or relative proportion of prey in the diet, at least given the errors we estimated using the bootstrap method. Ultimately, all parameters related to foraging success (PrCA and aging efficiency, but this was partially compensated by the error associated with the DLW method, which tended to underestimate foraging efficiency. These tendencies were similar between the 2 diet groups (Table S2), as well between this study and the Antarctic fur seal study (Jeanniard du Dot et al. 2017b). diet-related parameters) tended to overestimate for- 

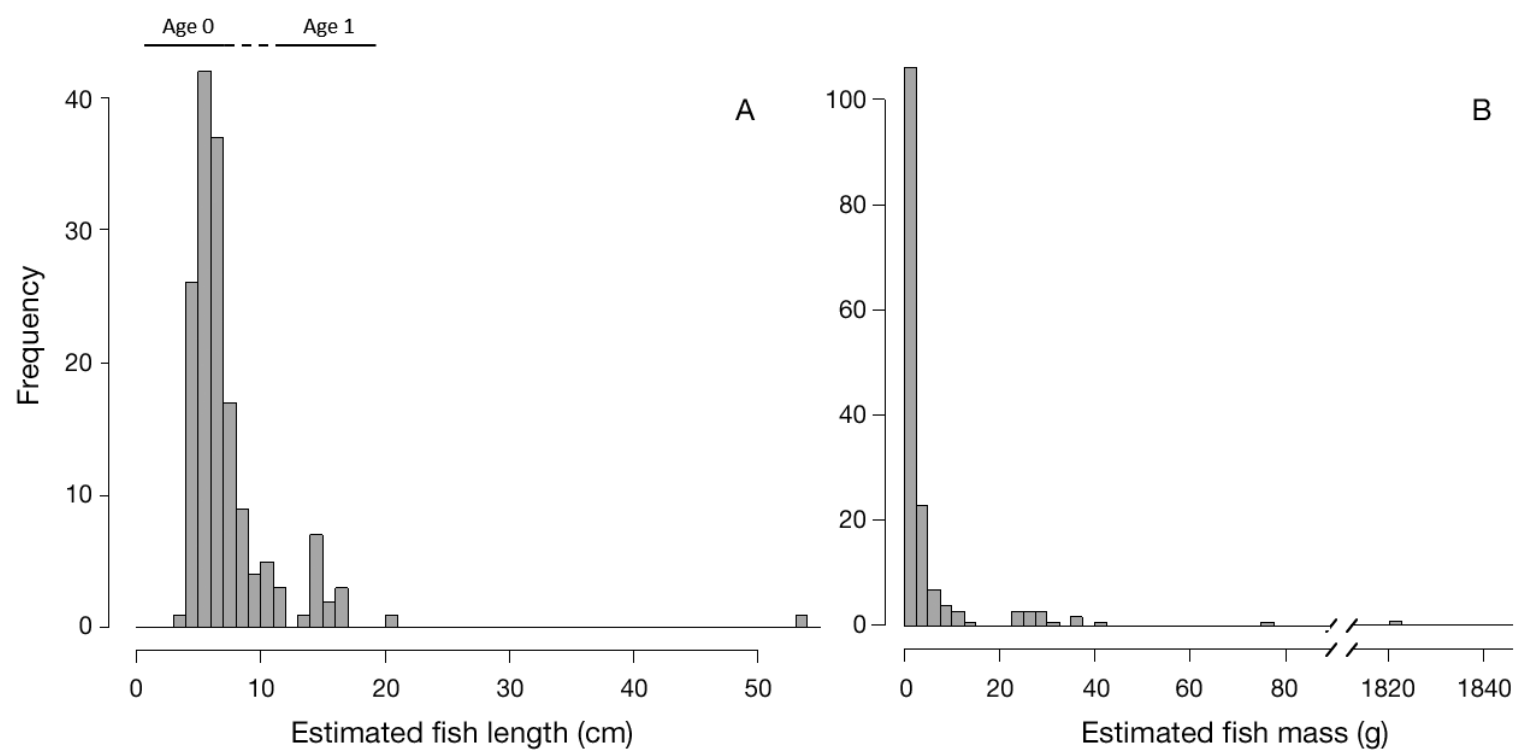

Fig. 3. Frequencies of walleye pollock (A) length and (B) mass consumed by female northern fur seals in the Bering Sea estimated from otolith size $(n=173)$ found in 98 scats collected on Reef Rookery, St. Paul Island, in August 2011 (Jeanniard du Dot et al. 2017a)

\section{DISCUSSION}

Food is not evenly distributed in space and time in the ocean, so acquiring it requires animals to make behavioural 'decisions' as to where, when, and for how long to search for food. Such decisions or foraging strategies will affect energy expenditure as well as the amount of energy animals manage to extract from their habitat. Since energy is one of the fundamental currencies of foraging ecology underlying behavioural, physiological, reproductive and developmental traits and capacities, the ratio between energy expenditure and gain from foraging is a pivotal tool to estimate the growth, survival and reproductive fitness of animals.

\section{Foraging efficiency varies with foraging strategy}

The 20 female northern fur seals we tracked from Reef Rookery employed 2 foraging strategies that were indicative of different prey bases and distributions (Boyd 1996, Forcada \& Staniland 2009). A minority $(40 \%)$ of the females foraged in oceanic waters over the deep basin. They travelled greater distances, spent more time at sea and less time diving, and made shallower dives of shorter durations ( $15 \mathrm{~m}$ for $\sim 40$ s) compared to the remaining $60 \%$ of the females that foraged in neritic waters $(\sim 40 \mathrm{~m}$ for $\sim 80 \mathrm{~s})$. The oceanic females fed at night on primarily mesopelagic fish such as northern smoothtongue or myctophids, i.e. on small energy-dense schooling fish that migrate diurnally towards the surface at night (Jeanniard du Dot et al. 2017a). In contrast, neritic females dove benthically to the relatively shallow bottom of the Bering Sea shelf $(\sim 150 \mathrm{~m})$. On average, the neritic females spent $15 \%$ of their time diving to the bottom (defined as within $95 \%$ of bathymetric depth) during night and day, and fed mostly on gadids or other shelf-associated prey. Neritic females tended to obtain less energy per gram of prey ingested because they fed on a diet that was $44 \%$ lower in energy density than that of oceanic females. However, the neritic females fed on bigger prey, which resulted in $~ 60 \%$ more energy per average prey item ingested compared to the average prey consumed by oceanic females. These 2 foraging strategies based on location and diving behaviours have been observed in female fur seals from Russian and Alaskan breeding islands (Gentry 1998), but energetic costs associated with the 2 strategies within a single year have not been previously quantified.

Oceanic females spent less time diving overall, and attempted to capture 4 times more prey per minute spent diving compared to neritic females. Both strategies (oceanic and neritic) resulted in $\sim 1.76$ attempts to capture prey per dive in which at least one capture occurred. This value is within the range of prey capture attempts per dive measured in Antarctic fur seals, i.e $\sim 1.88$ recorded by Viviant et al. (2016), and $\sim 2$ by Jeanniard du Dot et al. (2017b). In addition to performing more (shorter) dives than neritic females, 
oceanic females also attempted to capture prey 3 times more often per day and had fewer unsuccessful dives (i.e. dives with no PrCA detected). They also had higher rates of energy gain than their neritic counterparts. A consequence of feeding further from the breeding beaches is that oceanic individuals expended slightly more energy during their foraging trip to and from foraging grounds. However, this increased cost of travelling further was compensated for by the relative energetic advantage that feeding in the deep basin offered them. Consequently, oceanic seals were more energetically efficient at foraging (3.03) compared to neritic seals (1.51).

Despite assumptions and uncertainties in our calculations (detailed in Jeanniard du Dot et al. 2017b), our estimates of foraging efficiency (from 1 to 3 ) are within in the range of 1 to 4 calculated for other birds and mammals (Hainsworth 1977, Stacey 1986, Parker et al. 1996, Weimerskirch et al. 2003a). However, all of these estimates are much lower than the foraging efficiency of 23 reported for northern fur seals in the 1980s (Costa 1993). This extremely high efficiency was derived using an isotopic method to estimate changes in body water content, and was based on the assumption that the seals were mainly eating squids.
Squids have a high water content and may not have been the dominant prey of the seals studied by Costa (1993), based on the results of more recent studies (Antonelis et al. 1997, Gudmundson et al. 2006, Trites et al. 2015). In addition, the resolution of depth sensors used to record diving behaviours in the 1980s (10 m resolution; Costa 1993) likely resulted in a large proportion of short dives being missed $(\sim 40$ dives $\mathrm{d}^{-1}$ recorded per day in 1980s compared to $\sim 300$ dives $\mathrm{d}^{-1}$ in this study), and thus in an underestimation of feeding events. As such, energy gain estimated in the in this 1980s study may have been inflated by a factor of 5 or more, thereby overestimating the true foraging efficiency of fur seals.

\section{Conflict between time and energy currencies in maternal investment}

Both neritic and oceanic strategies had average foraging efficiencies greater than 1 , indicating that the lactating females obtained enough energy to meet their own physiological needs (although more than half the females in the neritic group had FE $<1$; Table 3). However, lactation and the cost of pup

Table 3. Measured and corrected energy expenditure (EE), prey capture attempts (PrCA), energy gain, and foraging efficiency during single foraging trips of individual female northern fur seals (NFS) breeding on rookeries on St. Paul Island and foraging in the Bering Sea. Seals foraged either in neritic waters on the shelf (upper rows, $\mathrm{n}=9$ ) or in ocean waters in the basin (lower rows, $\mathrm{n}=7$ ). Mean values $( \pm \mathrm{SD})$, as well as average energy content per average prey $\left(E C_{p}\right)$, are also shown for each group. The corrected values of EE and PrCA (calculated as explained in 'Materials and methods; Foraging efficiency') were used with the estimated $E C_{p}$ to calculate the energy animals gained while foraging at sea and their foraging efficiency (i.e. the ratio of energy gain to energy expended)

\begin{tabular}{|c|c|c|c|c|c|c|c|}
\hline $\begin{array}{c}\text { Seal } \\
\text { ID }\end{array}$ & $\begin{array}{l}\text { Meas. } \\
\text { EE (MJ) }\end{array}$ & $\begin{array}{c}\text { Corr. } \\
\text { EE (MJ) }\end{array}$ & $\begin{array}{l}\text { Meas. } \\
\text { PrCA }\end{array}$ & $\begin{array}{l}\text { Corr. } \\
\text { PrCA }\end{array}$ & $\begin{array}{l}E C_{p} \\
(\mathrm{~kJ})\end{array}$ & $\begin{array}{c}\text { Energy } \\
\text { gain (MJ) }\end{array}$ & $\begin{array}{l}\text { Foraging } \\
\text { efficiency }\end{array}$ \\
\hline \multicolumn{8}{|l|}{ Neritic NFS } \\
\hline 1 & 367.43 & 360.55 & 1008 & 921 & $330.60 \pm 11.02$ & $303.65 \pm 52.13$ & $0.89 \pm 0.15$ \\
\hline 5 & 177.37 & 174.16 & 346 & 319 & & $104.91 \pm 17.62$ & $0.64 \pm 0.11$ \\
\hline 6 & 115.74 & 113.58 & 321 & 295 & & $97.83 \pm 16.54$ & $0.89 \pm 0.16$ \\
\hline 8 & 115.07 & 113.01 & 152 & 140 & & $46.24 \pm 7.81$ & $0.42 \pm 0.07$ \\
\hline 12 & 205.27 & 201.40 & 718 & 660 & & $218.73 \pm 37.50$ & $1.13 \pm 0.20$ \\
\hline 13 & 152.06 & 149.36 & 1681 & 1538 & & $513.94 \pm 86.87$ & $3.48 \pm 0.64$ \\
\hline 14 & 440.71 & 432.94 & 635 & 580 & & $192.28 \pm 33.15$ & $0.51 \pm 0.08$ \\
\hline 17 & 146.65 & 143.96 & 549 & 503 & & $165.83 \pm 28.66$ & $1.19 \pm 0.22$ \\
\hline 19 & 122.60 & 120.56 & 1693 & 1567 & & $517.47 \pm 88.11$ & $4.32 \pm 0.79$ \\
\hline Mean \pm SD & $204.77 \pm 39.40$ & $201.06 \pm 38.68$ & $789 \pm 189$ & $725 \pm 174$ & & $240.10 \pm 57.77$ & $1.51 \pm 0.69$ \\
\hline \multicolumn{8}{|c|}{ Oceanic NFS } \\
\hline 2 & 249.57 & 244.92 & 2727 & 2505 & $194.94 \pm 8.49$ & $486.06 \pm 85.02$ & $2.02 \pm 0.38$ \\
\hline 3 & 156.54 & 153.81 & 1474 & 1351 & & $265.36 \pm 45.81$ & $1.73 \pm 0.32$ \\
\hline 4 & 428.07 & 420.02 & 3576 & 3252 & & $641.52 \pm 113.62$ & $1.54 \pm 0.29$ \\
\hline 10 & 73.97 & 72.67 & 1996 & 1839 & & $361.00 \pm 62.35$ & $4.96 \pm 0.94$ \\
\hline 11 & 120.03 & 117.89 & 1518 & 1397 & & $272.40 \pm 47.53$ & $2.33 \pm 0.44$ \\
\hline 15 & 125.03 & 122.81 & 3654 & 3378 & & $656.14 \pm 112.83$ & $5.40 \pm 1.00$ \\
\hline 20 & 136.22 & 133.86 & 2381 & 2194 & & $419.78 \pm 74.39$ & $3.23 \pm 0.61$ \\
\hline Mean $\pm \mathrm{SD}$ & $184.20 \pm 45.40$ & $180.85 \pm 44.53$ & $2475 \pm 339$ & $2274 \pm 310$ & & $443.18 \pm 53.51$ & $3.03 \pm 0.60$ \\
\hline
\end{tabular}


growth is substantial (Arnould 1997, Goldsworthy et al. 2004). Mothers must therefore have higher foraging efficiencies to ensure their own survival as well as that of their pups (Bouten et al. 1994). As such, oceanic females that gain 3 times more energy than what they spend obtaining it are likely to have more energy overhead to invest in their pups than neritic females that obtain only 1.5 times more energy.

The greater energy surplus available to allocate to reproduction would suggest that oceanic females should produce bigger pups on average and have greater reproductive success than neritic females. However, energy gain is not the factor influencing overall allocation of energy to reproduction (Boggs 1992, Ydenberg et al. 1994). Maximizing the rate of energy delivery to pups (i.e. the frequency of nursing bouts) tends to produce bigger pups (Gentry \& Kooyman 1986, Costa 1993). In our study, where 2 different strategies coexisted within a population, neritic females foraging on the shelf made significantly shorter foraging trips compared to oceanic females foraging in the deep basin. As foraging trip duration does not affect time spent ashore nursing pups between foraging trips (Antonelis et al. 1990), the females that adopted the neritic strategy likely fed their pups $\sim 20$ to $25 \%$ more frequently (considering a consistent 2 -d difference in trip duration over the breeding season). This dichotomy in strategies was also observed in California sea lions Zalophus californianus, with deepdiving individuals that travelled shorter distances tending to spend more time at the rookery in presence of pup (McHuron et al. 2016). Under this scenario, neritic females likely increase their nursing bout rate, and might thus provide a growth advantage to their pup compared to oceanic females.

On the other hand, additional energy acquired by oceanic females has to be reflected in tissue and/or milk accretion. There are evidences that lactating Australian and Antarctic fur seals that spend more time at sea produce energy richer milk to compensate for the longer time their pups fasted (Arnould \& Boyd 1995, Arnould \& Hindell 1999). This is suggested by the limited milk lipid content data we collected on our tracked females (Fig. S1 in the Supplement). In addition, there is a general agreement that the composition of fur seal milk reflects what mothers fed on during the days or week prior to the nursing bout (Goebel 2002) and that oceanic females have significantly greater milk lipid content than neritic females (Hayden 2012). Consequently, oceanic females could direct their higher energy overhead to greater energy output per unit of time nursing. However, whether it is physiologically realistic to increase milk quality to such levels as to provide an identical yield of milk energy as neritic females and compensate for additional days of absence and fewer nursing bouts over the reproductive season (i.e. longer fasting time and greater weight loss of their pup) remains unclear (Gentry \& Holt 1986, Trillmich 1990).

The foraging strategies employed by northern fur seals are surprisingly similar to those of Antarctic fur seals feeding in similar habitats in the southern hemisphere (Jeanniard du Dot et al. 2017b). Time budgets (i.e. time at sea, distance travelled, and allocation of time to different activities) of fur seals in the sub-Antarctic were similar to those of neritic northern fur seals. However, energy acquisition (i.e. prey captures, diet and foraging efficiency etc.) of Antarctic fur seals was more similar to oceanic than neritic females. This indicates that northern fur seal individuals compromised on one of the limiting factors, i.e. time allocated to nursing versus energy overhead, whereas Antarctic fur seals from an increasing population did not have to do so (short foraging trips with high foraging efficiencies).

Foraging efficiency of Antarctic fur seal mothers is positively related to offspring growth (Jeanniard du Dot et al. 2017b), which means that, within the context of a single type of foraging strategy and diet composition within a population, females that forage more successfully than others will produce bigger pups at weaning that have greater chances of surviving their first year at sea (Lescroël et al. 2010). The fact that pup mass at weaning is directly linked to pup survival in seals (Doidge \& Croxall 1989, Baker \& Fowler 1992, Boltnev et al. 1998, McMahon et al. 2000, Hall et al. 2001, Beauplet et al. 2005) implies that female pinnipeds with the highest foraging efficiencies will likely have higher individual fitness. Unfortunately, we could not obtain pup growth data from mother-pup pairs to determine whether this relationship holds for northern fur seals (i.e. whether there was a difference in reproductive success between these 2 foraging and nursing strategies. However, we did collect mass-at-age data for pups (Fig. S2) as a population index of pup growth and global maternal investment to compare to data collected when the population was not declining, 15 or 30 yr previously (Boltnev et al. 1998, Donohue et al. 2000, Angliss \& Allen 2009). Analysis of variances on the slopes of these different models showed that pup growth in 2011 was slower than in the 1980s or 1996 ( $p<0.001$ in all cases, see the section 'Pup growth' in the Supplement). The current reduced growth rates of pups might reflect the fact that this compromise ultimately results in lower provisioning from mothers 
(whether by decrease of time feeding pups or energy available for lactation), but this needs confirmation using more robust and standardized data collection.

\section{Foraging strategies within the population}

The declining population of northern fur seals has experienced significant environmental changes around their breeding islands (Anderson \& Piatt 1999, Napp et al. 2000, Overland \& Stabeno 2004). Shifts in ocean climate have been hypothesized to be responsible for decreases in reproduction success of seabirds (Weimerskirch et al. 2003b) and marine mammals (Ferguson et al. 2005, Trites et al. 2007) by changing the availability, type and distribution of prey. In 2011, sea surface temperature on the shelf was colder, compared to the average over the previous $30 \mathrm{yr}$, but nearbottom temperature was warmer and bottom temperature was close to the average (Lauth \& Conner 2014). This data does not indicate a particularly difficult year for walleye pollock body condition (Heintz et al. 2013) or abundance (Lauth \& Conner 2014). There was no survey off the shelf in 2011 but water temperatures did not indicate outlier conditions.

The northern fur seal population on St. Paul Island might maintain 2 foraging strategies because they have similar net fitness outcomes, resulting in alternative evolutionary stable strategies (Hines 1987). This is the case for thick-billed murres Uria lomvia breeding in the Bering Sea that display similar neritic and oceanic strategies with no apparent difference in chick-feeding rates and fledging success (Paredes et al. 2015). In the case of fur seals, environmental conditions can affect foraging costs between years (Costa 2008), so the difference between both strategies in the population might be averaged in terms of fitness over several generations. It is possible that one strategy does better under particular environmental conditions, and having these 2 strategies in the population provides a buffer to changes in prey distribution/abundance under changing environmental conditions, as suggested for California sea lions (McHuron et al. 2016).

Our study provides a narrow window into the foraging ecology of northern fur seals. Even though there is evidence that the foraging behaviours (Call et al. 2008) and foraging efficiencies (Jeanniard du Dot et al. 2017b) of females are consistent within a year, extending conclusions beyond the timescale of our measurements should be done with caution. Antarctic fur seals in better body condition seem consistently more efficient over the breeding season at exploiting their uniform foraging habitat (Jeanniard du Dot et al. 2017b), but it might not be the case for northern fur seals that can alternate between 2 different habitats and diets. Flexibility or adaptability of females to environmental conditions likely operate at a longer timescale than that of our study. Therefore, our results in the reported short time window only allow educated inferences and conjectures regarding the consequences of foraging efficiencies on the fitness of individuals.

\section{CONCLUSION}

Despite the limitations of our study, our results provide interesting clues to the potential energy transfers to pups on St. Paul Island, and highlight the importance of investigating the series of events that link environmental conditions, animal behaviours, energy balance, fitness of individuals, and demographic parameters. It is noteworthy that females from an increasing population (Antarctic fur seals) can on average simultaneously 'optimize' foraging efficiency and frequency of feeding their pups, while females from a declining population (northern fur seals) are faced with a trade-off between these 2 objectives. There is a need to investigate whether one foraging strategy yields a lower reproductive success via lower survival of the young compared to the other, as this could ultimately lead to northern fur seals producing a significant portion of smaller pups at weaning, with lower survival during their first year and thus a lower recruitment into the population (Baker \& Fowler 1992). A possible next step could thus be to estimate the survival rate of juveniles over the first few years of their pelagic life, and determine how it relates to the foraging strategies of their mothers during their first 4 mo of life.

Data archive. The telemetry and DLW water data used in this study are deposited in Dryad for the article Jeanniard du Dot et al. (2016): Dryad Digital Repository: https://doi.org/ 10.5061/dryad.n8s3c. The diet data was provided in the Supplement to Jeanniard du Dot et al. (2017a).

Acknowledgements. We thank Al Baylis, Michelle Barbieri and Rachel Orben for their help in collecting the data, and the Energetics Research Lab at the University of Aberdeen for their help in analysing stable isotopes. We are also thankful to the North Pacific Research Board and to the Canada National Scientific and Engineering Research Council for their contribution in funding this project. All data were collected under the US NMFS permit \# 14329-01 and the University of British Columbia animal care permit \# A10-0364. 


\section{LITERATURE CITED}

Anderson PJ, Piatt JF (1999) Community reorganization in the Gulf of Alaska following ocean climate regime shift. Mar Ecol Prog Ser 189:117-123

Andrews AG, Farley EV, Moss JH, Murphy JM, Husoe EF (2009) Energy density and length of juvenile pink salmon Oncorhynchus gorbuscha in the eastern Bering Sea from 2004 to 2007: a period of relatively warm and cool sea surface temperatures. North Pac Anadromous Fish Comm Bull 5:183-189

Angliss RP, Allen BM (2009) Alaska marine mammal stock assessments, 2008. US Department of Commerce, NOAA Technical Memorandum NMFS-AFSC-193. National Marine Fisheries Service, Seattle, WA

Anthony JA, Roby DD, Turco KR (2000) Lipid content and energy density of forage fishes from the northern Gulf of Alaska. J Exp Mar Biol Ecol 248:53-78

Antonelis GA, Stewart BS, Perryman WF (1990) Foraging characteristics of female northern fur seals (Callorhinus ursinus) and California sea lions (Zalophus californianus). Can J Zool 68:150-158

Antonelis GA, Sinclair EH, Ream RR, Robson BW (1997) Inter-island variability in the diet of female northern fur seals (Callorhinus ursinus) in the Bering Sea. J Zool (Lond) 242:435-451

Arnould JPY (1997) Lactation and the cost of pup-rearing in Antarctic fur seals. Mar Mamm Sci 13:516-526

Arnould JPY, Boyd IL (1995) Inter- and intra-annual variation in milk composition in Antarctic fur seals (Arctocephalus gazella). Physiol Zool 68:1164-1180

Arnould JPY, Hindell MA (1999) The composition of Australian fur seal (Arctocephalus pusillus doriferus) milk throughout lactation. Physiol Biochem Zool 72:605-612

Baker JD, Fowler CW (1992) Pup weight and survival of northern fur seals, Callorhinus ursinus. J Zool (Lond) 227:231-238

Beauplet G, Barbraud C, Chambellant M, Guinet C (2005) Interannual variation in the post-weaning survival of subantarctic fur seals: influence of pup sex, growth rate, and environmental conditions. J Anim Ecol 74:1160-1172

Boggs CL (1992) Resource allocation: exploring connections between foraging and life history. Funct Ecol 6:508-518

Boltnev AI, York AE, Antonelis GA (1998) Northern fur seal young: interrelationships among birth size, growth, and survival. Can J Zool 76:843-854

Bouten CV, Westerterp KR, Verduin M, Janssen JD (1994) Assessment of energy expenditure for physical activity using a triaxial accelerometer. Med Sci Sports Exerc 26: 1516-1523

Boyd IL (1996) Temporal scales of foraging in a marine predator. Ecology 77:426-434

Butler PJ, Green JA, Boyd IL, Speakman JR (2004) Measuring metabolic rate in the field: the pros and cons of the doubly labelled water and heart rate methods. Funct Ecol 18:168-183

Call KA, Ream RR, Johnson D, Sterling JT, Towell RG (2008) Foraging route tactics and site fidelity of adult female northern fur seal (Callorhinus ursinus) around the Pribilof Islands. Deep Sea Res II 55:1883-1896

Clarke MR (1962) The identification of cephalopod beaks and the relationship between beak size and total body weight. Bull Br Mus (Nat Hist) Zool 8:419-480

Clarke MR (1986) A handbook for the identification of cephalopod beaks. Clarendon Press, Oxford
Conners ME, Hollowed AB, Brown E (2002) Retrospective analysis of Bering Sea bottom trawl surveys: regime shift and ecosystem reorganization. Prog Oceanogr 55: 209-222

Costa C (1993) The relationship between reproductive and foraging energetics and the evolution of the Pinnipedia. Symp Zool Soc Lond 66:293-313

Costa DP (1987) Isotopic methods for quantifying material and energy intake of free-ranging marine mammals. In: Huntley AC, Costa DP, Worthy GAJ, Castellini MA (eds) Approaches to marine mammal energetics. Allen Press, Lawrence, KA, p 43-66

Costa DP (2008) A conceptual model of the variation in parental attendance in response to environmental fluctuation: foraging energetics of lactating sea lions and fur seals. Aquatic Conserv: Mar Freshw Ecosyst 17:S44-S52

Costa DP, Gentry RL (1986) Free-ranging energetics of northern fur seals. In: Gentry RL, Kooyman GL (eds) Fur seals: maternal strategies on land and at sea. Princeton University Press, Princeton, NJ, p 79-101

*Dalton AJM, Rosen DAS, Trites AW (2014) Season and time of day affect the ability of accelerometry and the doubly labeled water methods to measure energy expenditure in northern fur seals (Callorhinus ursinus). J Exp Mar Biol Ecol 452:125-136

Doidge DW, Croxall JP (1989) Factors affecting weaning weight in Antarctic fur seals, Arctocephalus gazella at South Georgia. Polar Biol 9:155-160

* Donohue MJ, Costa DP, Goebel ME, Baker JD (2000) The ontogeny of metabolic rate and thermoregulatory capabilities of northern fur seal, Callorhinus ursinus, pups in air and water. J Exp Biol 203:1003-1016

Dragoo DE (1991) Food habits and productivity of kittiwakes and murres at St. George Island, Alaska. MSc thesis, University of Alaska Fairbanks, AK

Ferguson SH, Stirling I, McLoughlin P (2005) Climate change and ringed seal (Phoca hispida) recruitment in western Hudson Bay. Mar Mamm Sci 21:121-135

Forcada J, Staniland IJ (2009) Antarctic fur seal Arctocephalus gazella. In: Perrin WF, Wursig BG, Thewissen JGM (eds) Encyclopedia of marine mammals, Vol 2. Academic Press, San Diego, CA, p 36-42

Gallon S, Bailleul F, Charrassin JB, Guinet C, Bost CA, Handrich Y, Hindell M (2013) Identifying foraging events in deep diving southern elephant seals, Mirounga leonina, using acceleration data loggers. Deep Sea Res II 88-89: $14-22$

*Gende SM, Quinn TP, Willson MF, Heintz R, Scott TM (2004) Magnitude and fate of salmon-derived nutrients and energy in a coastal stream ecosystem. J Freshwat Ecol 19:149-160

Gentry RL (1998) Behavior and ecology of the northern fur seal. Princeton University Press, Princeton, NJ

Gentry RL, Holt JR (1986) Attendance behavior of northern fur seals. In: Gentry RL, Kooyman GL (eds) Fur seals: maternal strategies on land and at sea. Princeton University Press, Princeton, NJ, p 41-60

Gentry RL, Kooyman GL (eds) (1986) Fur seals: maternal strategies on land and at sea. Princeton University Press, Princeton, NJ

Goebel ME (2002) Northern fur seal lactation, attendance and reproductive success in 2 years of contrasting oceanography. PhD thesis, University of California, Santa Cruz, CA

Goldsworthy SD, Lea MA, Guinet C (2004) Comparison of 
mass-transfer and isotopic dilution methods for estimating milk intake in Antarctic fur seal pups. Polar Biol 27: 801-809

* Grebmeier JM, Overland JE, Moore SE, Farley EV and others (2006) A major ecosystem shift in the northern Bering Sea. Science 311:1461-1464

* Grémillet DJH, Plös AL (1994) The use of stomach temperature records for the calculation of daily food intake in cormorants. J Exp Biol 189:105-115

Gudmundson CJ, Zeppelin TK, Ream RR (2006) Application of two methods for determining diet of northern fur seals (Callorhinus ursinus). Fish Bull 104:445-455

Hainsworth FR (1977) Foraging efficiency and parental care in Colibri coruscans. Condor 79:69-75

*Hall AJ, McConnell BJ, Barker RJ (2001) Factors affecting first-year survival in grey seals and their implications for life history strategy. J Anim Ecol 70:138-149

Halsey LG, Green JA, Wilson RP, Frappell PB (2009) Accelerometry to estimate energy expenditure during activity: best practice with data loggers. Physiol Biochem Zool 82:396-404

Harvey JT, Loughlin TR, Perez MA, Oxman DS (2000) Relationship between fish size and otolith length for 63 species of fishes from the eastern north Pacific Ocean. US Department of Commerce, NOAA Technical Report NMFS 150, National Marine Fisheries Service, Seattle, WA

Hayden AB (2012) Variability in population trends, life history characteristics, and milk composition of northern fur seals in Alaska. MSc thesis, University of Alaska Fairbanks

*Heintz RA, Siddon EC, Farley EV, Napp JM (2013) Correlation between recruitment and fall condition of age-0 pollock (Theragra chalcogramma) from the eastern Bering Sea under varying climate conditions. Deep Sea Res II 94:150-156

*Hendry AP, Berg OK (1999) Secondary sexual characters, energy use, senescence, and the cost of reproduction in sockeye salmon. Can J Zool 77:1663-1681

Hindell M, Crocker DE, Mori Y, Tyack PL (2010) Foraging behaviour. In: Boyd IL, Bowen WD, Iverson SJ (eds) Marine mammal ecology and conservation: a handbook of techniques. Oxford University Press, Oxford, p 243-262

Hines WGS (1987) Evolutionary stable strategies: a review of basic theory. Theor Popul Biol 31:195-272

Hunt GL Jr, Eppley Z, Burgeson B, Squibb R (1980) Reproductive ecology, foods and foraging areas of seabirds nesting on the Pribilof Islands, 1975-1979. Environmental assessment of the Alaskan continental shelf: final report of the principal investigators. NOAA Environmental Research Laboratory, Boulder, CO

Insley SJ, Robson BW, Yack T, Ream RR, Burgess W (2008) Acoustic determination of activity and flipper stroke rate in foraging northern fur seal females. Endang Species Res 4:147-155

Iverson SJ, Frost KJ, Lang SLC (2002) Fat content and fatty acid composition of forage fish and invertebrates in Prince William Sound, Alaska: factors contributing to among and within species variability. Mar Ecol Prog Ser 241:161-181

Jeanniard du Dot T, Guinet C, Arnould JPY, Speakman JR, Trites AW (2016) Accelerometers can measure total and activity-specific energy expenditures in free-ranging marine mammals only if linked to time-activity budgets. Funct Ecol 131:377-386
Jeanniard du Dot T, Thomas AC, Cherel Y, Trites AW, Guinet C (2017a) Combining hard-part and DNA analyses of scats with biologging and stable isotopes can reveal different diet compositions and feeding strategies within a fur seal population. Mar Ecol Prog Ser 584:1-16

Jeanniard du Dot T, Trites AW, Arnould JPY, Guinet C (2017b) Reproductive success is energetically linked to foraging efficiency in Antarctic fur seals. PLOS ONE 12: $\mathrm{e} 0174001$

Jeanniard du Dot T, Trites AW, Arnould JPY, Speakman JR, Guinet C (2017c) Activity-specific metabolic rates for diving, transiting, and resting at sea can be estimated from time-activity budgets in free-ranging marine mammals. Ecol Evol 7:2969-2976

Kuhn CE, Costa DP (2006) Identifying and quantifying prey consumption using stomach temperature change in pinnipeds. J Exp Biol 209:4524-4532

Lauth RR, Conner J (2014) Eastern Bering Sea continental shelf bottom trawl survey of groundfish and invertebrate fauna. US Department of Commerce, NOAA Technical Memorandum NMFS-AFSC 350, National Marine Fisheries Service, Seattle, WA

* Lea MA, Guinet C, Cherel Y, Duhamel G, Dubroca L, Pruvost $P$, Hindell M (2006) Impacts of climatic anomalies on provisioning strategies of a Southern Ocean predator. Mar Ecol Prog Ser 310:77-94

* Lescroël A, Ballard G, Toniolo V, Barton KJ, Wilson PR, Lyver POB, Ainley DG (2010) Working less to gain more: When breeding quality relates to foraging efficiency. Ecology 91:2044-2055

Logerwell E, Christiansen RA (2000) Energy density of Steller sea lion prey in western Alaska: species, regional, and seasonal differences. Poster presented at the symposium on 'Marine Science for the Northeast Pacific: Science for resource-dependent communities.' in Anchorage, AK

Kuque SP, Arnould JPY, Miller EH, Cherel Y, Guinet C (2007) Foraging behaviour of sympatric Antarctic and subantarctic fur seals: Does their contrasting duration of lactation make a difference? Mar Biol 152:213-224

McHuron EA, Robinson PW, Simmons SE, Kuhn CE, Fowler M, Costa DP (2016) Foraging strategies of a generalist marine predator inhabiting a dynamic environment. Oecologia 182:995-1005

*McMahon CR, Burton HR, Bester M (2000) Weaning mass and the future survival of juvenile southern elephant seals, Mirounga leonina, at Macquarie Island. Antarct Sci 12:149-153

Muto MM, Helker VT, Angliss RP, Allen BA and others (2016) Alaska marine mammal stock assessments, 2016. US Department of Commerce, NOAA Technical Memorandum NMFS-AFSC-355, National Marine Fisheries Service, Seattle, WA

Napp JM, Kendall AW, Schumacher JD (2000) A synthesis of biological and physical processes affecting the feeding environment of larval walleye pollock (Theragra chalcogramma) in the eastern Bering Sea. Fish Oceanogr 9: $147-162$

Overland JE, Stabeno PJ (2004) Is the climate of the Bering Sea warming and affecting the ecosystem? Eos (Wash DC) 85(33):309-316

Paredes R, Orben RA, Roby DD, Irons DB and others (2015) Foraging ecology during nesting influences body size in a pursuit-diving seabird. Mar Ecol Prog Ser 533:261-276

* Parker KL, Gillingham MP, Hanley TA, Robbins CT (1996) 
Foraging efficiency: energy expenditure versus energy gain in free-ranging black-tailed deer. Can J Zool 74: 442-450

Paul AJ, Paul JM (1999) Interannual and regional variations in body length, weight and energy content of age-0 Pacific herring from Prince William Sound, Alaska. J Fish Biol 54:996-1001

Perez MA (1994) Calorimetry measurements of energy value of some Alaskan fishes and squids. US Department of Commerce, NOAA Technical Memorandum NMFSAFSC-32. National Marine Fisheries Service, Seattle, WA

Pinheiro JC, Bates DM (2000) Mixed-effects models in S and S-PLUS. Springer, New York, NY

Reid K, Forcada J (2005) Causes of offspring mortality in the Antarctic fur seal, Arctocephalus gazella: the interaction of density dependence and ecosystem variability. Can J Zool 83:604-609

Rosen DAS, Trites AW (2000) Digestive efficiency and drymatter digestibility in Steller sea lions fed herring, pollock, squid, and salmon. Can J Zool 78:234-239

Sinclair EH, Vlietstra LS, Johnson DS, Zeppelin TK and others (2008) Patterns in prey use among fur seals and seabirds in the Pribilof Islands. Deep Sea Res II 55: 1897-1918

Sparling CE, Thompson D, Fedak MA, Gallon SL, Speakman JR (2008) Estimating field metabolic rates of pinnipeds: doubly labelled water gets the seal of approval. Funct Ecol 22:245-254

Speakman JR (1997) Doubly labelled water: theory and practice. Chapman \& Hall, London

Speakman JR, Nair KS, Goran MI (1993) Revised equations for calculating $\mathrm{CO}_{2}$ production from doubly labeled water in humans. Am J Physiol 264:E912-E917

Stacey PB (1986) Group size and foraging efficiency in yellow baboons. Behav Ecol Sociobiol 18:175-187

Tollit DJ, Steward MJ, Thompson PM, Pierce GJ, Santos MB, Hughes S (1997) Species and size differences in the digestion of otoliths and beaks: implications for estimates of pinniped diet composition. Can J Fish Aquat Sci 54: 105-119

Tollit DJ, Heaslip S, Zepplelin T, Joy R, Call K, Trites AW (2004) A method to improve size estimates of walleye pollock (Theragra chalcogramma) and Atka mackerel (Pleurogrammus monopterygius) consumed by pinnipeds: digestion correction factors applied to bones and otoliths recovered in scats. Fish Bull 102:498-508

Trillmich F (1990) The behavioral ecology of maternal effort in fur seals and sea lions. Behaviour 114:3-20

*Trites AW, Calkins DG (2008) Diets of mature male and female Steller sea lions (Eumetopias jubatus) differ and cannot be used as proxies for each other. Aquat Mamm $34: 25-34$

Trites AW, Miller AJ, Maschner HDG, Alexander MA and

Editorial responsibility: Elliott Hazen,

Pacific Grove, California, USA others (2007) Bottom-up forcing and the decline of Steller sea lions (Eumetopias jubatus) in Alaska: assessing the ocean climate hypothesis. Fish Oceanogr 16:46-67

Trites AW, Battaile BC, Benoit-Bird KJ, Cooper LW and others (2015) Patch dynamics study. NPRB BSIERP Projects B67 and B77 final report. North Pacific Research Board, Anchorage, AK

V Van Pelt TI, Piatt JF, Lance BK, Roby DD (1997) Proximate composition and energy density of some North Pacific forage fishes. Comp Biochem Physiol A 118:1393-1398

Viviant M, Trites AW, Rosen DAS, Monestiez P, Guinet C (2010) Prey capture attempts can be detected in Steller sea lions and other marine predators using accelerometers. Polar Biol 33:713-719

*Viviant M, Jeanniard-du-Dot T, Monestiez P, Authier M, Guinet C (2016) Bottom time does not always predict prey encounter rate in Antarctic fur seals. Funct Ecol 30: 1834-1844

Vollenweider JJ, Heintz RA, Schaufler L, Bradshaw R (2011) Seasonal cycles in whole-body proximate composition and energy content of forage fish vary with water depth. Mar Biol 158:413-427

*Volpov BL, Hoskins AJ, Battaile B, Viviant M and others (2015) Identification of prey captures in Australian fur seals (Arctocephalus pusillus doriferus) using headmounted accelerometers: field validation with animalborne video cameras. PLOS ONE 10:e0128789

*Wanless S, Harris MP, Redman P, Speakman JR (2005) Low energy values of fish as a probable cause of a major seabird breeding failure in the North Sea. Mar Ecol Prog Ser 294:1-8

W Weimerskirch H, Ancel A, Caloin M, Zahariev A, Spagiari J, Kersten M, Chastel O (2003a) Foraging efficiency and adjustment of energy expenditure in a pelagic seabird provisioning its chick. J Anim Ecol 72:500-508

Weimerskirch H, Inchausti P, Guinet C, Barbraud C (2003b) Trends in bird and seal populations as indicators of a system shift in the Southern Ocean. Antarct Sci 15: 249-256

Whitman LD (2010) Variation in the energy density of forage fishes and invertebrates from the Southeastern Bering Sea. MSc thesis, Oregon State University, Corvallis, OR

Wolff GA (1984) Identification and estimation of size from beaks of 18 species of cephalopods from the Pacific ocean. In: NOAA Tech Rep NMFS 17

*Y Yenberg RC, Welham CVJ, Schmid-Hempel R, SchmidHempel P, Beauchamp G (1994) Time and energy constraints and the relationships between currencies in foraging theory. Behav Ecol 5:28-34

Keppelin TK, Orr AJ (2010) Stable isotope and scat analyses indicate diet and habitat partitioning in northern fur seals Callorhinus ursinus across the eastern Pacific. Mar Ecol Prog Ser 409:241-253

Submitted: September 4, 2017; Accepted: May 11, 2018 Proofs received from author(s): July 18, 2018 